\title{
Dhows in doldrums: a spotlight on an informal segment of Pakistan's maritime economy
}

\author{
Ms. Alifiya AunAli ${ }^{1}$ \\ Cdr Sajjad Ahmed Khrbey ${ }^{2}$
}

\section{Abstract}

This paper elaborates upon the challenges faced by Dhow making industry in Pakistan, where dhows have always served as the traditional means of cargo transportation. Dhows have also been useful in trade especially with secondary ports and war -torn countries of the Middle East and Africa. The decreasing trend in trade through dhows is affecting not only the maritime economy but also may lead to the extinction of traditional and customary knowledge of dhow making industry. Pakistan needs to ensure that policy gaps are filled to address the concerns of all stakeholders and steps may be taken to identify it as a formal industry in the maritime economy.

Moreover, training and capacity building programs will also play an eminent role in generating relevant workforce for boosting the growth of the boat making industry. Active efforts are needed for Public Private Partnership and incentivizing dhow trade also with the assurance of the availability of required raw materials that would help in the revival of the industry. The utilization of modern technology, adequate facilities such as revision of port charges and availability of basic infrastructure are recommended to excel the growth of this vital segment of maritime economy.

Keywords: Trade, wooden boats, traditional boats, sea-trade, flag- state, traditional art, voyage

Sajjad Ahmed Khrbey is a Deputy Director - National Institute of Maritime Affairs (NIMA) Karachi reachable at ddadmin.ncmpr@bahria.edu.pk

Ms. Alifiya AunAli is a KPT Research Associate - National Institute of Maritime Affairs (NIMA) Karachi reachable at alifiya.aun@gmail.com 


\section{INTRODUCTION}

Boat-building is an ancient art that is as old as the period of Hazrat Nooh (Noah) (A.S); we all know over the rage, there has been a development in tools and technique, of course, but the process remains no less fascinating and enchanting. ${ }^{1}$ Approximately above $90 \%$ of international trade occurs via maritime transport by using either ocean transport, ${ }^{2}$ seaways or inland waterways, the role of maritime transportation is considered to be crucial in international trades. ${ }^{3}$ The maritime trade is undertaken through large, medium and small ships and boats/dhows. While talking about the maritime trade in the Indian Ocean the role of traditional wooden dhows cannot be overemphasized. These dhows sail throughout the year and especially are used with smaller secondary ports/anchorages. They have become a vital link with for trade with poor and war-torn countries like Somalia and Yemen.

In Pakistan, Dhows have been engaged in cargo transportation since historic times. The trade through dhows is operated by Trading Agents. These agents are listed with the local authorities and government agencies. Shippers' complete paperwork and make payments in the agent's office. These Trading Agents work on 3\% of the freight value of the entire cargo as their commission. At present only three Trading Agents are engaged in the dhows trading business in Pakistan they are M/s Noor Sons, M/s Al- Faizan and Lateef Trading Company. Whereas there were more than twenty companies operating in the past in the said business, most companies have left the business due to the downward trade trend. One of the dhow shipping agents stated that only 80 to 100 Dhows from different countries come to Pakistan annually for trading, whereas it was about 800 plus in the past (about 10 years back).

${ }^{1}$ Mehar-un-nisa, "Boatcraftsmanship:Arisingtide.” The Express Tribune, Sunday Magazine, August 16, 2015.

2 Peter Vine, Pearls in Arabian Waters: The Heritage of Bahrain. (London: Immel, 1986.)

${ }^{3}$ Funda Yercan and Turkay Yildiz, "International Maritime and Trade logistics", Maritime Logistics: A Complete Guide to Effective Shipping and Port Management, 3 (2012): 23-44. 
At present, not a single Pakistani Dhow is engaged in trading which means that all the Dhows engaged in the transportation of goods to and from Pakistan are not registered in Pakistan. They are mostly registered in Iran, UAE, Comoros, Togo, India etc. Registration of dhows in Pakistan was stopped in 2003 by the MMD department as quoted by one of the Trading Agents. ${ }^{4}$ Besides, there are many other challenges being faced by this very important economic activity. There is a growing fear and distress that the traditional knowledge of dhow making in Pakistan is in danger of becoming extinct. This segment of maritime economy plays a significant role thus it is considered very important to preserve the traditional knowledge, bring innovations and mainstream it at parity with emergent international trends.

In mentioned context above, this paper suggests necessary measures to strengthen and uplift the status of traditional dhow making industry and its business in Pakistan by highlighting and underlining the importance of traditional knowledge and significance in overall maritime economy of Pakistan, Understanding various issues and modern international utilization trends.

The paper also employs qualitative research methodology and has scrutinized and examined the relevant primary and secondary sources of data / information by means of boat construction site visits and nine Key Informant Interviews of the relevant stakeholders of the industry i.e. Timber Merchants at Timber market, Boat Building Craftsman at Boat Building Yard at Machar Colony, Nakhodas (Captains) of Pakistani Dhows, the boat owner of biggest boat built in Pakistan, Dhows Trading Agents at Keamari, Nakhoda (Captain) of an Irani Dhow at Ghas Bandar Jetty KPT Karachi, Mercantile Marine Department Karachi, a Tour Operator at Marina Club DHA Karachi and a Trading Agent at Kharadar Karachi. Pictures were taken during the field visit of boat construction sites. Visits to the Boat construction sites' were undertaken at Karachi and Gwadar for hands-on observations.

4 Interview with the representatives of Irfan M. M/s Noor sons Trading Agent Company, 6 August, 2019. 


\section{Origin of Dhows: An Overview}

The term 'Dhows' is derived from the ${ }^{5}$ Arabic word dawa, these were traditional boats used in the Indian 'Ocean, Persian Gulf and Red Sea regions. These were originally sailing vessels which consisted of triangular sails. Conflicting theories also exist as to whether dhows originated in India, the ${ }^{7}$ Middle East or in ${ }^{8}$ East Africa; regardless of this, the dhow manufacturing industry had been traditionally one of the most vital manufacturing industries of the Persian Gulf region. ${ }^{9}$ The Chinese till date, uses traditional boats similar dhows, which go by the name of 'Junks'. From as early as the 2 nd century AD, junks were utilized to go to the sea, and they developed at a fast pace in the period of the Song dynasty, the Junk boats has been one of the major inventions of the Song dynasty There are countless reasons why the junk boat is one of the most important inventions by the song dynasty but here are two main reasons first is its redesigned hull and rear rudders (960-1279). The dhows boat making has also been traditionally and customarily allied with the sub-continent region and was used for trade, this traditional art and skill has been a permanent part of the boat making industry of this region.

The wooden boats, that have become extinct in the global shipping arena, are still favourites in South Asia, which has an inconsiderable financial return for the builders and their customers. ${ }^{10}$

5 Dhow nativevessel used on the Arabian Sea. XIX. ult. orig. unkn.; in Marathias ḍāwa in Arabic as dāwa.

${ }^{6}$ Malcolm C. peck, Encyclopedia of the Modern Middle East and North Africa Peck, (2020)

7 Laith Ulaby, "On the Decks of Dhows: Musical Traditions of Oman and the Indian Ocean World." The World of Music, 1,2 (2012):43-62.

8 Poonam Bala, "Dhow Cultures of theIndian Ocean: Cosmopolitanism, Commerceand Islam.” African Historical Review, 44:1,(2012): 138-142.

9 The mariners' museum and park, "Junk Ship" https://exploration.marinersmuseum.org/ watercraft/junk-ship/, accessed on 24.9.2019

${ }^{10}$ Mansoor Hassan, "Wooden boats still alive in South Asia". Dawn News, February 18, 2018. 


\section{Types of Dhows}

Dhows are different from other traditional cargo ships in various aspects. One of these is due to their structure and shape. The Dhows are also simple in their design, which enables them to have more space for hull cargo. Dhows have been designed primarily for gulf-waters by enabling them to drift upon shallow waters and constructing them so that they are easily manoeuvrable. They also consist of triangular sails, long stems and sharp bows in order to make them seaworthy especially to the Monsoon season in the Indian Ocean. Over time, dhows have evolved. Engines have been incorporated including electric generators. Commercial cargoes today are transported via motorized dhows through the Indian Ocean. In few countries, dhows are also being partially constructed from fibre glass instead of wood; they are also getting bigger in size and some have also been custom-made as floating small luxury hotels/restaurants and even ferries.

There are numerous types of Dhows some for deep sea and some for shallow waters, which are used for all kinds of transportation and fishing. There are mainly 13 types of dhows with more than 200 distinctive designs. ${ }^{11}$ The Dhows are differentiated on the bases of their size and hull design as well as based on their regional difference in both colours and ornamentation. The size of the largest boat being presently built has increased from 300-500 tons to 700-2000 tons or even more. Identification of Dhows according to their build, style or origin is not very simple thing. Each Dhow is unique with variation in size, shape, and colour. A Dhow's wooden wheelhouse and other superstructures can be carved into traditional designs and customized modifications which may be visible that vary from region to region. Traditional Dhows can be divided into 5 main categories i.e. Shu'ai Dhow (small or medium sized general purpose boat, range from 5 to 15 meters in length), Jalibut or Jelbut with square stern (advanced version of the Shu'ai Dhow, ranging up to 15 meters in length),

11 "NATO Identification guidefor Dhows, Skiffs and Whalers in the High Risk Area," NATO Shipping Centre, accessed September 24, 2019, http://maritimeconnector.com/documents/NATO Guidance.pdf 
Yemeni (small and medium sized boat, approximately 15 meters in length), Boum (large 'ocean going' Dhow, ranges from 15 to 35 meters or more in length) and Sambuq (other large Dhow). A boum in full sail is represented in the emblem of Kuwait emphasizing its traditional importance in the country, where it was used in the pearl industry, to carry fresh water and as a trading ship. Other dhows include Sambuk or Sambuq, Baghlah, Ghanjah or Kotiya, Jahazi or Jihazi, Battil, Barijah, Baqarah or baggarah (derived from the Arabic word for "cow"), Zaruq and Badan etc.

\section{Basic Features of Different Types of Dhows}

Few details of basic features of different types of Dhows as mentioned below:

a. Shu'ai A Shu'ai ${ }^{12}$ Dhow is a small or medium sized general- purpose boat. The sizes of these vessels range from 5 to 15 meters (18 - 50 feet) in length. It is used for cargo transportation and fishing. The boat has a particular curved profile, high and square at the stern, becomes low towards the bow and then ascends to a trademark extending pointed head. Shu'ai Dhow has a transom stern with decorative projections that stretch out beyond the hull as a continuation of the deck rail.
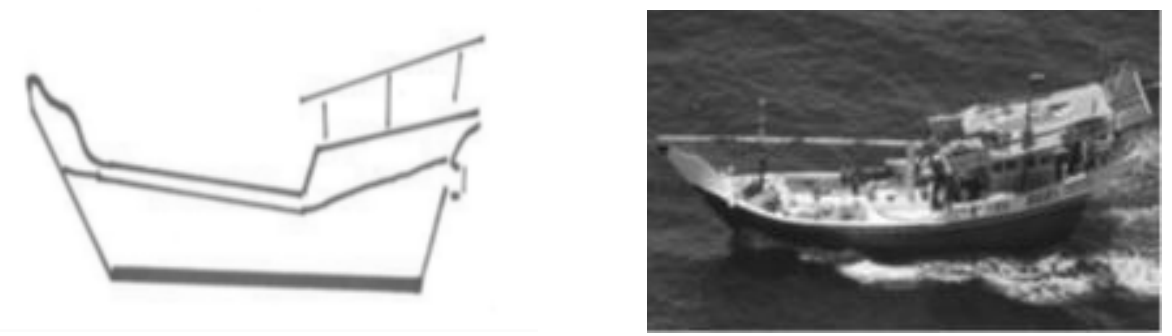

b. Yemeni This is a small and medium sized boat, approximately 15 meters (50 feet) in length. These boats are uniquely designed for fishing and are common along the Yemeni coastline. This Dhow has either a transom type or decreased high rising stern and a steep angled pointed bow.

12 “ NATO Identification guide” 

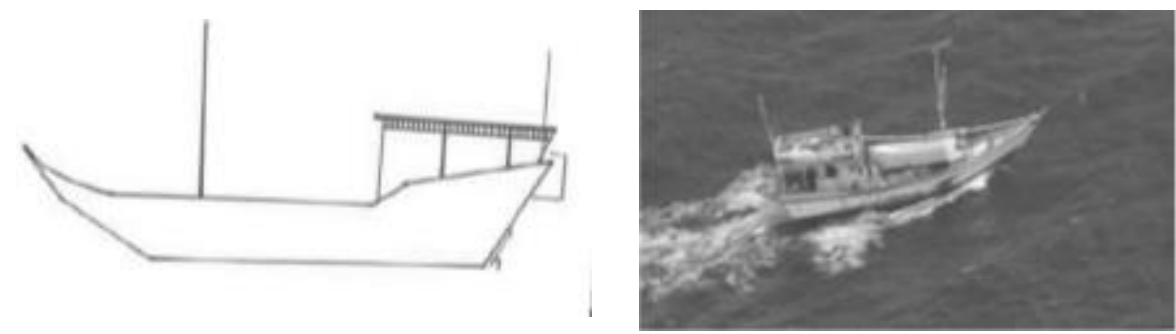

c. Jalibut or Jelbut with square stern A Jelbut is a small to medium-sized Dhow, ranging up to 15 meters (50 feet) in length. It is the advanced version of the shu'ai with a shorter head stem piece. Most Jelbut Dhows are fitted with engines. The Jelbut is used in the trading and fishing industries and historically, was used extensively as a pearling vessel. The Jelbut Dhow fe atures a transom stern, with a short, rowed stem-piece rising vertically from the waterline, giving the vessel a rectangular bow profile. Pakistani boat builders make these types of boats.
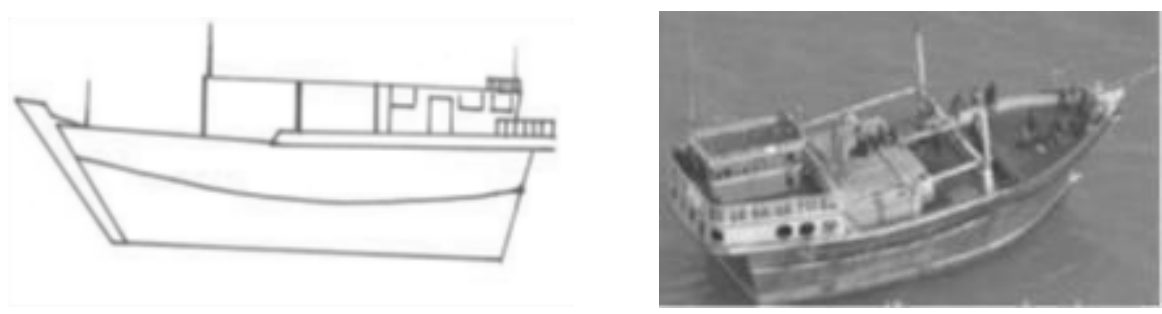

d. Jalibut or jelbut with round stern This Dhow features a short-bow and a stern with a round shape. Except from the stern, the Dhow is similar to the Jelbut with the square stern.
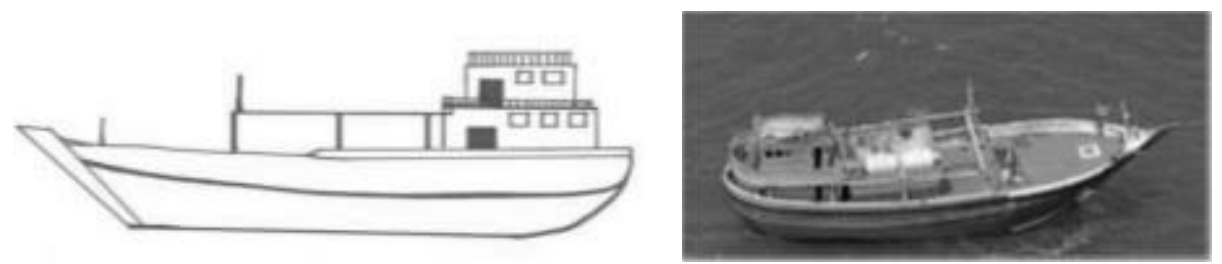

e. Boum or dhangi The BOUM and the SAMBUQ are the two larges 'ocean going' Dhows. The Boum is a large sized Dhow and ranges from 15 to 35 meters (50 - 115 feet) or more in length. These vessels are used as transport vessels for passengers and goods. A boum in full sail is represented in the emblem of Kuwait 
emphasizing its traditional importance in the country, where it was used in the pearl industry, to carry fresh water and as a trading ship.

Divers often used to use this dhow as a diving boat as it has a tempered stern, The Boum had an imposing high bow on the original Arab style Boum which is trimmed in the latest version and the Indian version (known as Dhangi in India). It has an outboard rudder higher than the stern.
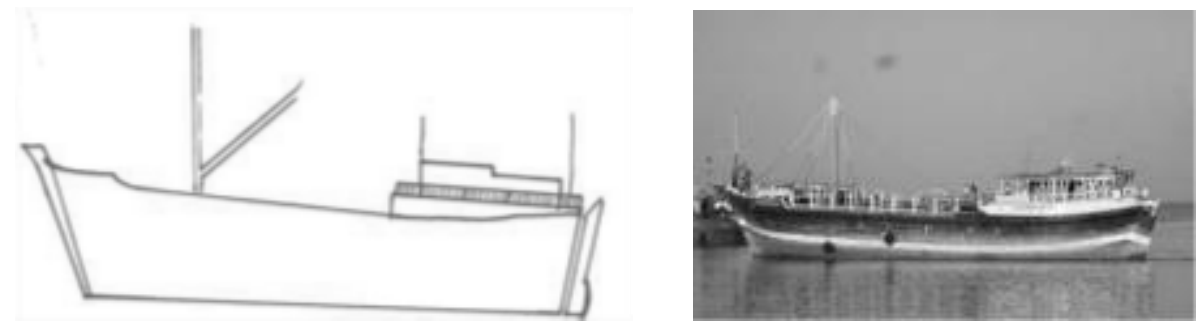

f. Sambuk or sambuq Being 38 meters ( 124 feet), the sambuq is one of the largest dhows and it can transport greater than 500 tons. In the Middle East, these dhows are utilized for the transportation of passengers and cargo. They are also used in loading and unloading operations. The design of the sambuq originates from India and Europe; these dhows have a square or transom stern and previously consisted of detailed carvings.
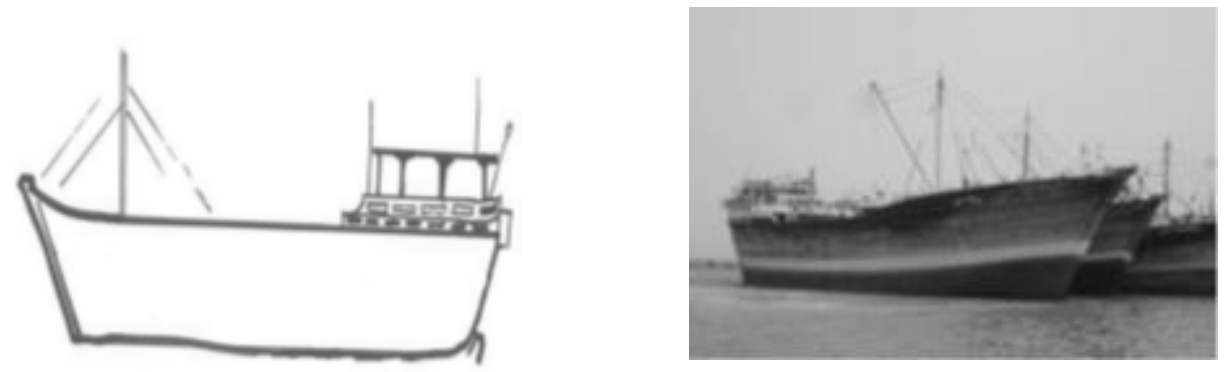

Traditionally, a Sambuk had one or two masts, but nowadays they are motorized. It has been one of the most successful Dhows in history. It has a special keel design, with a sharp curve right below the top of the bow. The Sambuq either has a rounded or a squared stern. 


\section{Identification of Dhows by Origin}

The different dhows can be identified by area where they have been built. ${ }^{13}$ Boat makers and designers are likely to build and decorate their Dhows in certain specific and distinctive patterns even though it is likely to fade with time as new materials, engines, size; cargo handling systems are also built-in in the modern builtDhows.

The Pakistani Dhows are often painted, and the designs done are more elaborate (blue or turquoise on the superstructure), and the hulls of the dhows are often shallower and slightly less rounded. Registration number is usually written on the hull under the superstructure and the name of the vessel is also painted at the same place.

Indian Dhows consist of a wide and rounded hull. These are plain boats, and the hull is not painted with a white superstructure. The registration number is painted white along with the side of the hull under the superstructure which, also incorporates the name of the vessel.

The Dhows of UAE are smaller than the Indian Dhows and are often more decorated. ${ }^{14}$ These dhows are primarily used for recreation, for fishing and transportation of cargo transportation in the Middle Eastern region. They often have a noticeable "cutter" on the bow. Their hull is overextended and turns up sharply at the stern. However, few owners from UAE have started constructing their boats through Pakistani boat builders.

Yemeni Dhows are generally similar to UAE Dhows, a little smaller than the Pakistan and Indian Dhows and are often less

13 Carl Waldman, and Alan Wexler, Encyclopedia of Exploration, Vol. 1-2., (NewYork:

Facts on File, 2004)

${ }_{14}$ Shirley Kay, Bahrain: Island Heritage. Dubai, United Arab Emirates: Motivate Pub, 1989). 
seagoing vessels. ${ }^{15}$ These dhows usually take on to shorter trips to Djibouti, Somalia and the UAE. These boats are easy to manoeuvre and can be identified by the square hull at the stern with a low sweep towards the bow.

\section{Traditional Boat Building in Pakistan - An Informal Industry}

Wooden boats have been built in Pakistan traditionally since generations. It is an industry in the informal sector in which thousands of people are engaged. The sector employs boat designers, carpenters and vendors of various materials used in boat building. These boats are built in mostly in the cities like Karachi and Gwadar are used for the purpose of fishing and Cargo. The most popular area where Pakistani wooden boats are built in large number is the Boat Building Yard at the Karachi Fish Harbour Authority. In Karachi one will find the construction of various sizes of boats for the purpose of fishing and cargo transportation. In addition, these boats are also being built along the coastal belt of Karachi like Ibrahim Haideri, Younisabad and Machar Colony.

Pakistani craftsmen use various kinds of woods to build different sizes of boats for fishing and cargo transportation. ${ }^{16}$ Burma teak or teak from Indonesia is the ideal wood to use due to its longevity and sturdiness of the wooden dhows. Additionally, local wood types such as Keekar, Laachi and Saras are also used in the construction process. However, many of the workers in the yard expressed reservations that if deforestation in Pakistan continues with the same pace, the availability of wood for boats will become limited and more costly to procure.

The engines used in the wooden boats are imported from Singapore, China and some are smuggled from Afghanistan. Different woods apart from Burma Teak (local name Sagwan), Rosewood (local name Sheesham or Tali), Acacia Wood (commo nly known as Keekar), include Eucalyptus Wood (local name Safeda),

\footnotetext{
15 Dionisius A. Agius, John P. Cooper, and Chiara Zazzaro, “The Maritime Heritage of Yemen: A Focus on Traditional Wooden 'Dhows'," Archaeopress Archaeology, (2014): 143-157.

16 Mehar-un-nisa, “Boat craftsmanship: A rising tide.”
} 
Balau Wood (grown in the Pacific-Asia region) and Bilinga Wood (alternate of Balau wood, imported from Africa).

\section{Construction Process of Boats / Dhows}

The Pakistani craftsmen make fishing boats and cargo dhows for domestic and international clients. They also supply their products to Iran, ${ }^{17} \mathrm{Yemen}$, Saudi Arabia, and UAE. Pakistani boat builders do not require any technical drawings, graphs, or any type of design. They also do not even use modern gadgets/frames to make a boat. It is an inherited profession, and the skill is transferred from generation to generation to the workers who are carpenters and have learnt the boat construction skills from their forefathers. While building a normal boat for fishing purposes, they use a team of 7 members, including some 'Waada' (carpenters) and for making a large size cargo boats, they require at least 20 skilled men. The prices of these boats fluctuate depending upon the requirement of the size and the quality of the wood to be used in the construction. These craftsmen built these vessels in multiple stages.

First to lay the boat's foundation, first the craftsmen cuts the selected trunk of the tree for the keel of the boat, they call it "Pathan" or "Tar". Then they cut the Forefoot and Sternpost 'Agla Mora' and 'Pichla Mora' of the boat and join them with keel. After that they place the Ribs - the internal wooden structure of the boat, locally known as 'Dhancha'. For this, they mostly use Pakistani wood 'Taali/Sheesham (Rosewood) or Keekar (Acacia).

On the completion of the internal structure, they start attaching the outside wooden hull in a curved shape with wooden planks which are fixed with nuts and bolts. For the hull of the boat, they use the 'Bilinga' wood, which is imported from Malaysia and South Africa. When the outer hull is completed, they start fixing the pillars and beams for placing the deck (floor of the boat) on it. These pillars and beams are normally of wood, but iron girders are also used in medium and large boats. In the cargo boats (Dhows) they make two additional decks at the stern of the boat.

${ }_{17}$ Alan Villiers, "Some Aspects of the Arab DhowTrade", Middle East Journal, 2, no.4, (1948), 399-416, https://www.jstor.org/stable/4322010. 
Subsequently, various compartments are then constructed in the boat comprising of a galley, an Engine room, Control/Steering room, one or two Washrooms, Captain/ Nakoah room and Rest Room for the crew. The major space of the boat is utilized for the storage of cargo. Constructions of these compartments depend on the size and availability of the space on the boat. A small boat doesn't have such luxuries, it only has a small space for a toilet and cooking.

They also apply fish fats (mixed with some chemicals) on the outer part of the boat's hulls which remain in the water. These fish fats improve the durability of wood from adverse effects of the sea water and make it waterproof. To make the boat beautiful, paintwork, traditional carvings and other finishing work on the various parts of the boat is done. The boat is then lowered down into the sea water for the final touch ups and installation of engine, propellers, generators, electrical/ mechanical gear and accessories.

The hull of Dhows is constructed deeper for storing a maximum quantity of cargo, which make the dhows more stable and balanced as compared to other boats. The construction of these boats can take up from 06 months to 24 months on average depending on the size of the boat subject to availability of finances with the owner of the boat. Figures 1 to 3 show different steps of dhow construction in Pakistan. ${ }^{18}$

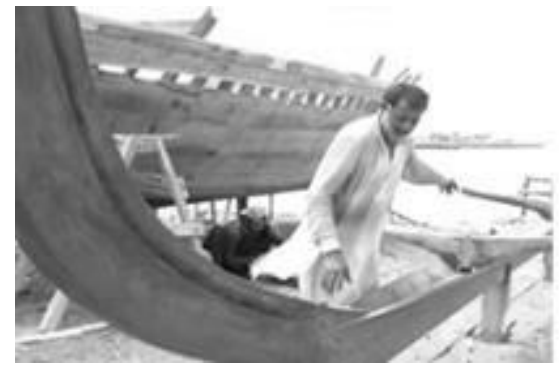

Figure 1: Laying Keel of the Boat with Forefoot and Sternpost. (Source: NCMPR Depository)

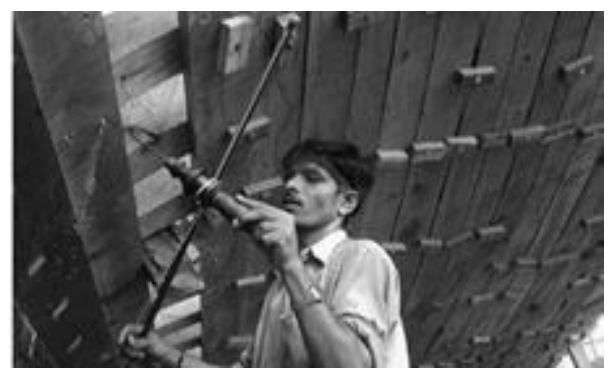

Figure 2: Fixing Wooden Wall on the Ribs of the Boat.(Source: NCMPR Depository)

${ }^{18}$ MuhammadUsman, BoatBuilding CraftsmanatBoat BuildingYard, MacharColony Karachi, July 2019. 


\section{Financial Aspects and Various Economic Practices in Boat Building Business}

The price of a small boat starts from one million and it can go up to more than 15 million. The cost of the boat building is directly proportional to the size of the boat built, quality of wood being utilized, engines and other related materials, whereas the cost of a medium/large sized boat would be approx. Rs. 100-150 million or in some cases more. The largest boat recently built in Karachi is for 2000 tons. This cargo boat (Dhow) is 175 feet long, 25 feet deep and 55 feet wide and to date has cost Rs. 110 million, whereas 2 $\mathrm{x}$ engines, a generator, a crane and other related accessories of the boat are yet to be installed on which a further amount of approximately Rs.40 to 60 million will be required. Unfortunately, due to lack of any governmental / Institutional support, the large dhows are towed to Dubai for engine fittings.

It is imperative to mention that due to the non-availability of proper dhow building quays and lowering machinery/cranes, these owners have to bear substantial expenditure on the lowering of medium of large boats in the Sea. One of the craftsmen informed that they had recently had to pay approximately Rs. 8 million on just lowering of a 2000 ton boat into the sea.

Working Practices for Boat Building Industry There is no proper boat building company in Pakistan, mostly the boat building is undertaken by few artisans who are known by word of mouth and are well reputed due to their class of work and quality, and this is the reason that demands for Pakistani boats and Craftsmen is increasing especially in Dubai, Iran and other countries. The boat building crew in Pakistan professionally do not follow any blueprint or drawing while constructing the boats. ${ }^{19}$ They have learnt by heart their methods and do not need any graphs, pictures or drawings to guide their hand. Since drawings, charts, and layouts are unusual objects for these craftsmen, they usually ask the owner's requirements in detail while booking their

19 Khurshid Ahmed, "Pakistan's craftsmen build boats withoutlayouts and sketches", Arab News Pakistan, February 11, 2018, https://www.arabnews.pk/node/1244106/pakistan. 
orders. Normally they ask about the material that is to be used, especially the wood, the size of the boat and other things related to the boat building. Regardless of the conventional system construction used by the labour, the Pakistani Boat Building is known for its skilled craftsmanship.

Currently, most of the builders are taking orders for cargo vessels since the demand for fishing boats have decreased; this is due to a range of reasons, including the continuous use of over- aged vessels. The life of wooden boats is also much longer usability than fibre glass boats as per the perception prevailing in Dhow owners. The average life of these boats is approximately 25 years and a large number of fishermen procure old vessels as most of them cannot afford the new ones. On average 30 to 40 boats for the purpose of fishing and cargo are built every year. This is over and above the repair work in the yard that rarely comes to an end. The Karachi Fish Harbour Authority (KFHA) charges Rs 100/- per boat (per day) from boat builders for providing space in the Boat Building Yard.

\section{Crew Management \& Payment Methods}

The Number of crew members for a Dhow construction varies from 5-30 in number, depending on the size and usage of the Dhow. Smaller Dhows may require 5-10 members, average or standard sized dhows may have 12-18 crew members and large Dhows may have 20-30. Even today, the general crew is often comprised of individuals without formal seamanship or fishery training. A few of the captains/Nakhoda ${ }^{20}$, are the owners of the boats, and the crew is somewhat poorly paid.

In the past, Arabs have traditionally been part of the Arabian dhows crew, but today their participation has declined. Today most Dhows consist of Indian, Pakistani and Iranian crew. Dubai and Comoros dhows are fully manned by Pakistani crew, whereas Iranian dhows have 5-10\% Pakistani crew. Indian and Pakistani Dhows are manned by the local crew.

${ }^{20}$ Nakhodi is a term originating from the Persian language which literally means Captain. ... Derived from nāvboat (from Old Persian) + khudā master, from MiddlePersian khutāi a 'master of a native vessel' or 'Lord of the Ship'. 
The Pakistani Dhow crew is either paid on a daily or a weekly basis. Currently, they are getting paid Rs. $1200-1500$ per day and the captain of the dhow gets double of that amount. The other system of payment to the crew is to divide the income of the dhow into three parts; after deducting the entire expenditure of fuel, spares and provisions, the owner gets two parts while the rest is distributed amongst the crew and the Captain is paid double that of the crew. ${ }^{21}$

\section{Registration of Boats and Flag State}

Dhows fly flags of those states in which they are registered; at present there have been an increasing number of owners who are registering their vessels in flag of convenience States, with mostly with the owner situated in other country than that of the flag state. However, the state flag is flown in international waters; while in the national waters of any country, the Dhow flies the local flag of the country, the Dhow is in the country of. This is to primarily escape the local taxations and is a local practice which is not recognized under International law.

Pakistani boat builders despite having built so many dhows but not a single dhow is Pakistani flagged. All Pakistani Dhows are flagged in the state of convenience, mostly in Dubai, or few of them in Comoros and Togo. ${ }^{22}$ Some of the Pakistani dhow holders have tried in the past to get their dhows registered in Pakistan, but there is no well-defined and clear procedure with Mercantile Marine Department (MMD) for registration of cargo Dhows, however, the department is registering fishing boats. The MMD officials were approached with the query; they have indicated to resolve the said issue onpriority. ${ }^{23}$

${ }^{21}$ Younus M, and Buksh M, Nakoha (Captain), Dhow, July, 2019.

22, Anwar M of M/s Noor Sons, and Pervaiz M of M/s Al Faizan, Dhows Trading Agents

Karachi, June, 2019.

23 Captain Shaheen A, Mercantile, Marine Department, Karachi July, 2019. 


\section{Trade through Dhows inPakistan}

Commodities which are being imported to Pakistan through the Dhows include machinery, motor vehicles (reconditioned), electronic equipment/gadgetries, animals, general items and personal baggage from UAE, Muscat, Kuwait and Somalia. Limited export is being undertaken through Dhows which comprises of rice, flour, fruits etc. to, Somalia, Yemen, Iran, UAE and all the Gulf Countries. Previously, animals were also exported from Pakistan but now a ban has been imposed on animals' import and export. Napier Mole Jetty (Ghas Bandar) is dedicated at KPT (Karachi Port Trust) for the Embarkation/Disembarkation of cargo. Only 4 to 6 Dhows can be accommodated on this jetty depending on the size of the boats. The remaining can be adjusted alongside the boats. All cargo on the Dhows is manually handled by shore labour. The cargo of these boats generally carries smaller packages which can be manually loaded and discharged. The labourers at the dock physically carry the goods up and down the boat, for the heavier packages either the Dhow's lifter or shore cranes are used to do the job.

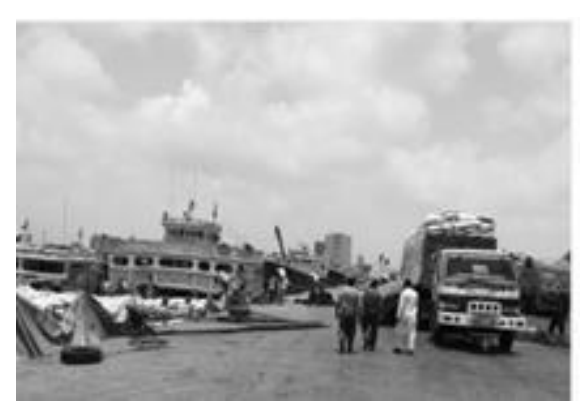

Fig 5: Cargo arrived by a truck, for dhows at Ghas. Bandar (Source: NCMPR Depository)

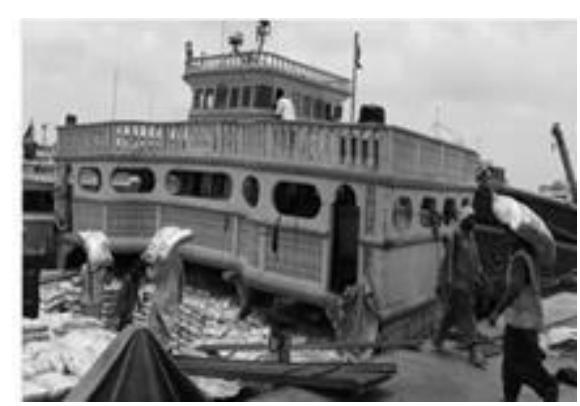

Fig 6: Labourers loading cargo on dhows at Ghas Bandar (Source: NCMPR Depository) 
The following shortcomings / problems regarding port facilitie s were highlighted during an interview with a Captain of a dhow. These issues need immediate attention for the improvement of trade through dhows: ${ }^{2425}$

a. Port charges are on the higher side and need to be revised.

b. Facilities especially bathrooms are in very poor conditions.

c. No fresh water supply line is available at the jetty.

d. Heavy amount is being charged by KPT for the permit to supply rations and fresh water through dedicated agents.

e. Large boats of 1800 tons and above cannot come at the Jetty due to less depth as dredging is required at Ghas ${ }^{26}$ Bander.

\section{Modern Utilization Trends of Dhows}

Pakistani Dhows are commonly utilized either for fishing or Cargo transportation. Whereas Dhows are being used for many purposes internationally and are a good source of earning including foreign exchange. For instance, Maldivian Dhows locally known as "Dhonis" are utilized for live aboard floating hotels and as ferries for excursion trips. These Dhows are constructed beautifully, having all modern luxuries required by the foreign tourists from all over the globe. During a visit to Marina Club DHA, Karachi, it has been noted that few Dhows stationed at anchor have been converted from fishing boats into excursion boats

24 Anwar M of M/s Noor Sons and Pervaiz M of M/s Al Faizan Dhows Trading Agents Karachi, June, 2019.

25 Ghani A. a Nakoha(Captain) ofa Irani Dhow at Ghas BandarJetty KPT Karachi, June, 2019/ 
and have cabins, kitchens, washrooms and other required facilities. These boats (captured by Law enforcement agencies) were purchased in auction and were converted into recreational boats for family picnics by the private owners. It is worth mentioning here that these types of boats can be utilized and operated by the tourism department or it can be operated by private tour operators for locals and foreign tourists and can be a good source to generate revenue and income.

\section{Recommendations}

Pakistan is at the forefront of traditional Boat Building in the region, however other regional centres are emerging due to lack of support from the Government. In order to save Dhow businesses in Pakistan, the following recommendations are mentioned:

1. The government needs to revisit the existing governance gaps and make friendly policies to the boat constructors and tour operators in order to promote this sector and mainstream this neglected sector of maritime economy by declaring it as a mainstream Industry.

2. The Karachi Fish Harbour Authority (KFHA) needs to provide better facilities to the boat builders at the Boat Building Yard. Apart from the provision of utilities and other basic services, the most important requirement is to establish a permanent launching machinery/ infrastructure for lowering down of the constructed boats into the sea. Boat builders can pay some additional charges to avail this facility as presently they are paying a substantial amount for this aforementioned purpose, which increases the overall boat building cost.

3. The government needs to provide consultancy facilities to the boat builders by hiring qualified experts in boat designing and building business and ensure availability of proper drawing/ layouts for building good quality boats using modern, techniques. Moreover, on long term basis courses may be introduced at technical colleges/ University level for producing Architectures/ Engineers with specialization in boat building. 
4. The government needs to encourage the private sector by providing them certain incentives to start ferry services and recreational facilities for the masses through Dhows.

5. The government also needs to be responsible for the motivations to the exporters to trade through dhows in the region as due to it being costeffective in its nature their exports will be more competitive.

6. Today, the wooden boat industry is not feasible and not much profitable due to the unavailability of good quality wood. Initially, boats were made up of Burma teak, which is not affordable now; then our boat builders started using Sheesham wood which is also becoming non-existent; then they started using Balau wood which they imported from Malaysia, which is also not available now in the market. In the international market, the wooden boats are dominated by luxury yachts at the higher market end and provide smooth sail and high-performance boats at the lower end. People are using carbon fibre composites to reduce weight and drag and modern, efficient engines, and modern scientific techniques to improve performance. If Pakistan wants to increase her share in the market, it needs to come into the fibre boat industry and train and build capacity of its human resource and make them adaptable to use modern techniques and practises.

7. There are some great opportunities for ships/boat and Dhows Building in Gwadar: as presently the city of Gwadar has a modest wooden boat building yard with top-notch skills and excellent manufacturing output 27

8. Cargo Dhows coming to Karachi from various countries are stationed at the NMB Wharf (locally known as Ghass Bandar) for the loading and unloading of the cargo where insufficient facilities are available. The Port Authority has to make improvements in the following areas to promote/increase the growth of this informal but important segment of maritime economy.

${ }_{27}$ NaghmanaZafar, "WorldBank's PROBLUEPlanandopportunities for Pakistan," The Financial Daily, views and opinions, January 20, 2020. 
a. Port charges are considerably on the higher side and needs to be reduced from the current rates.

b. The Water Supply is not available at the jetty. Dhow agents arrange water bowsers and ration from outside. They pay additional wharfage to the Port Authorities for taking these water bowsers and ration trucks to the Port area, where the dhows are docked which makes the water and ration expensive. The Port Authority is required to arrange the water supply through pipe lines as it is being provided to the bigger ships. 